\title{
2-mercaptoethanol のマウスリンパ球による
}

\section{in vitro 抗体産生促進機構}

\author{
大森 斉・山本 格*
}

\begin{abstract}
A mechanism of augmentation of in vitro antibody response by 2-mercaptoethanol in murine lymphocytes The mechanism of augmentation of antibody response in vitro by 2-mer captoethanol (2 ME) was investigated. By employing cystine-free RPMI-1640 medium, it was demonstrated that cystine was absolutely required for eliciting the in vitro antibody response in murine lymphocytes. The augmentation by $2 \mathrm{ME}$ was com pletely dependent on the presence of cystine. Maximal response was reached when cysteine or cystine (as half cystine) was added at $2.5 \mathrm{mM}$ where $2 \mathrm{ME}$ did not further enhanced the response. The serial feeding of cysteine, but not of cystine, amplified its potentiating activity at lower concentrations $(\leqq 1 \mathrm{mM})$. The addition of $10^{-5} \mathrm{M} 2 \mathrm{ME}$ to the medium shifted the dose-response curve to lower concentrations by about one order of magnitude. It was found that ${ }^{35} \mathrm{~S}$-cystine was incorporated into lymphocytes one fifth more slowly than ${ }^{35} \mathrm{~S}$-cysteine. Cystine uptake was accelerated by about $2.5-$ fold in the presence of $10^{-5} \mathrm{M} 2 \mathrm{ME}$. A close correlation was observed between doseresponse profiles of $2 \mathrm{ME}$ in augmenting the antibody response and the stimulation of cystine uptake. These data suggest that one of the roles of $2 \mathrm{ME}$ in augmenting antibody response in vitro is to facilitate the uptake of cystine which is contained in RPMI-1640 medium and which is utilized less efficiently than cysteine.
\end{abstract}

Hitoshi Ohmori - ItaruYamamoto Department of Medicinal Biochemistry, Faculty of Pharmaceutical Sciences, Okayama University

2-メルカプトエタノール(2 ME) が，抗体産生 ${ }^{1)}$ や, 細胞障害性 $\mathrm{T}$ 細胞の誘導 ${ }^{2}$ などの in vitro のリンパ球反 応を増強することはよく知られている。 この化合物は, これらのリンパ球反応を効率よく行らための有用な添加 物として広く用いられているにもかかわらず，その作用 機作については統一的結論が得られていない，2MEの in vitro 抗体産生促進は, $2 \mathrm{ME}$ にるるシ 胎児血清 （FCS）成分の活性化を介して起こるという報告があ

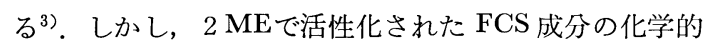
性状については，なにもわかっていない，

最近, Hoffeld (4) $^{4}$ (2 $2 \mathrm{ME}$ の抗体産生増強における 役割は，FCS に含まれ細胞毒性のある酸化型グルタチ オン (GSSG) をその還元型（GSH）に変換することで あると報告している。

一方, 筆者らは $2 \mathrm{ME}$ をはじめ種々のチオール化合物 の mitogen 活性と抗体産生促進能力を比較し, 両者に 相関性のあることを見いだした ${ }^{5)}$.この研究の過程で, GSHよりも高い還元電位を有し従って GSSG を還元で きない cysteine を $5 \mathrm{mM}$ 程度の高濃度加えれば, $2 \mathrm{ME}$ $\left(10^{-5} \mathrm{M}\right)$ と同程度の促進効果が得られることを見いだし

* 岡山大学薬学部生物薬品製造教室
た。さらに, cysteine の新鮮な溶液を $12 \mathrm{hr}$ ごとに逐時 添加した場合は, 最大の応答促進に必要な cysteine の濃 度は $0.5 \mathrm{mM}$ 程度にまで低下した。一方, cystine でも cysteine とほぼ同程度に抗体産生を促進することができ たが，この場合は逐時添加の効果がまったく認められな かった。一方, リンパ球の培養条件では, cysteine は急 速に cystine 飞酸化されてしま $5^{6)}$ ことを考虑すると, 以上の結果は, リンパ球が cystine よりも cysteine を 抗体産生促進のために効率よく利用することを示唆して いる。またリンパ球培養に用いる RPMI-1640 培地は, cysteine cystine の形で含有している.

本論文に执いて，筆者らは，マウスリンパ球による in vitro 抗体産生は培地中の cystine 飞完全に依存する こと, および $2 \mathrm{ME}$ は cystine のリンパ球への取り込 み反応を促進することによって，抗体産生を增強するこ とを示唆する結果を得たので報告する。

\section{材料と方法}

(1) 実験材料

$\mathrm{BALB} / \mathrm{c}$ マウス（ㅇ）は，6週龄のものを日本チャー ルズリバーから購入し，10〜15週秢で使用した。試薬お よび培地は，つぎのところから入手した， 


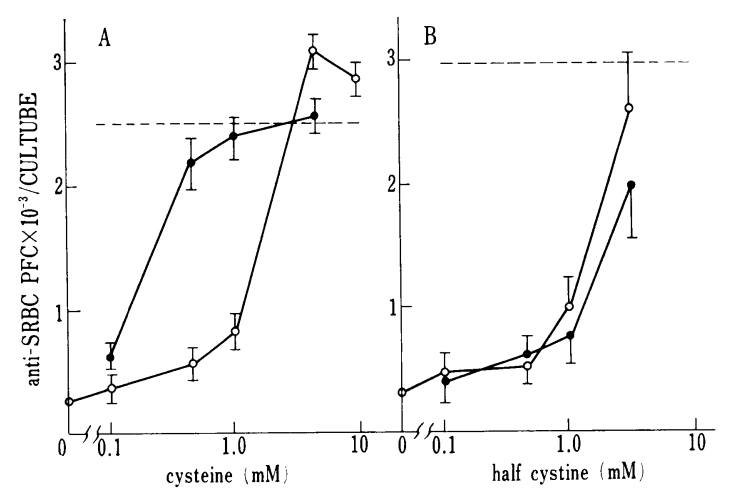

图 1 effect of serial addition of cysteine or cystine on the antibody response to $\mathrm{SRBC}$ in vitro

BALB $/$ c spleen cells $\left(8 \times 10^{6}\right)$ were cultured with $2 \times 10^{6} \mathrm{SRBC}$ in $2 \mathrm{ml}$ of RPMI-1640 medium containing 10\% FCS for 4 days in the presence of cystine, cysteine or $2 \mathrm{ME}$.

(o) added once at the start, (•) added serially every $12 \mathrm{hr},(\cdots) 2 \mathrm{ME} 10^{-5} \mathrm{M}$.

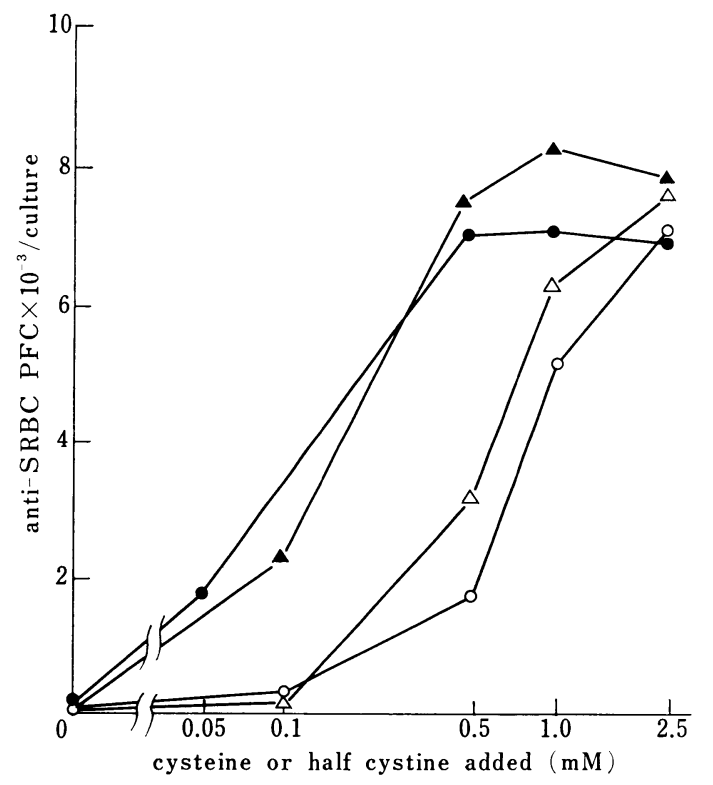

図 2 effect of cystine or cysteine concentrations on the antibody response to SRBC in vitro in the presence or absence of $2 \mathrm{ME}$

BALB/c spleen cells $\left(6 \times 10^{6}\right)$ were cultured with $2 \times 10^{6}$ SRBC in $\mathrm{Cys}^{-}-\mathrm{RPMI}-1640$ medium in the presence of the indicated amount of cystine or cysteine for 4 days. When cysteine was added every $12 \mathrm{hr}$, the concentrations indicate the total amount of cysteine added after the final addition.

$(0)$ cystine, $(\Delta)$ cysteine, $(\bullet)$ cystine plus $2 \mathrm{ME}\left(10^{-5} \mathrm{M}\right)$, ( $\mathbf{\Lambda}$ ) cysteine added every $12 \mathrm{hr}$.

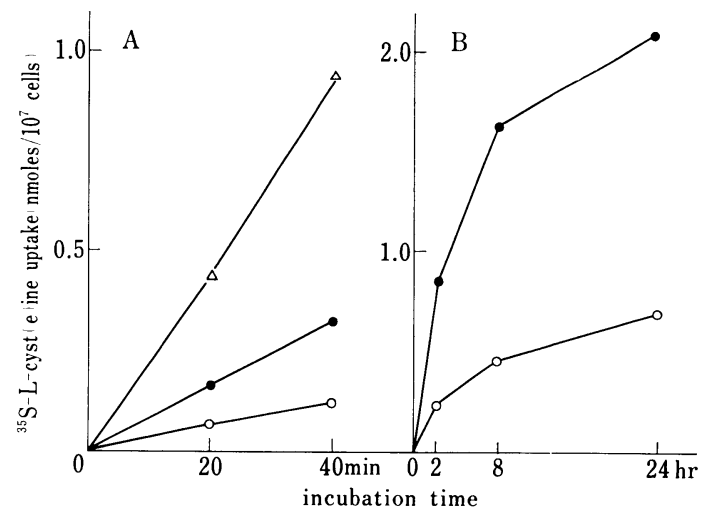

図 3 effect of $2 \mathrm{ME}$ on the rate of cystine uptake by murine lymphocytes

RBC-depleted spleen cells $\left(6 \times 10^{6}\right)$ were incubated at $37^{\circ} \mathrm{C}$ for the time indicated in $1 \mathrm{ml}$ of cystine-free RPMI-1640 medium which was supplemented with $10 \%$ FCS and $0.1 \mathrm{mM}{ }^{35} \mathrm{~S}$-half cystine or ${ }^{35} \mathrm{~S}$-cysteine $(0.5 \mu \mathrm{Ci})$.

( ० ) ${ }^{35} \mathrm{~S}$-cystine, $(\bullet)^{35} \mathrm{~S}$-cystine pl us $2 \mathrm{ME}$ $\left(10^{-5} \mathrm{M}\right),(\Delta)^{35} \mathrm{~S}-$ cysteine (in the presence of $0.2 \mathrm{mM}$ DTT).
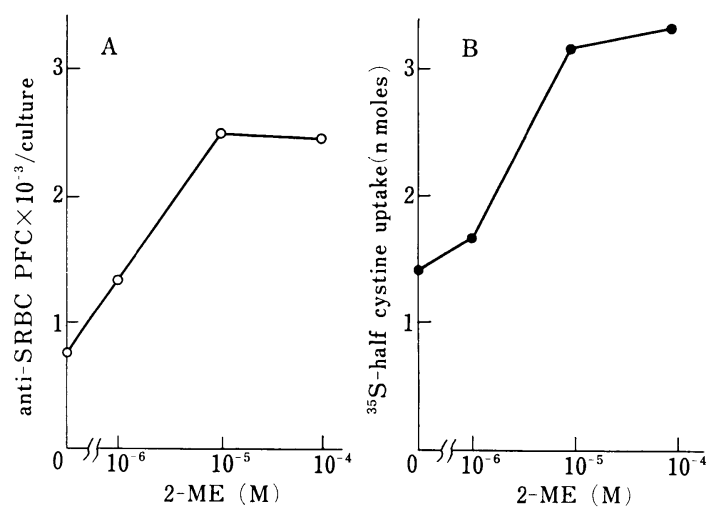

図 4 dose-response profiles of $2 \mathrm{ME}$ in the enhancement of the antibody response in vitro and cystine uptake in murine lymphocytes

A : Effect of $2 \mathrm{ME}$ on the antibody response to $\mathrm{SRBC}$ in vitro. $\mathrm{BALB} / \mathrm{c}$ spleen cells $\left(8 \times 10^{6}\right)$ were cultured with $2 \times 10^{6} \mathrm{SRBC}$ in the presence of $2 \mathrm{ME}$ for 4 days.

B : Effect of $2 \mathrm{ME}$ on cystine uptake. RBC-depleted spleen cells $\left(6 \times 10^{6}\right)$ were incubated with $0.37 \mathrm{mM}^{35} \mathrm{~S}$-half cystine $(2 \mu \mathrm{Ci})$ for $60 \mathrm{~min}$. 
表 1 cysteine requirement of murine lymphocytes for eliciting primary antibody response to $\mathrm{SRBC}$ in vitro

\begin{tabular}{lcc}
\hline $\begin{array}{l}\text { culture } \\
\text { medium }\end{array}$ & $\begin{array}{c}2 \mathrm{ME} \\
(10-5 \mathrm{M})\end{array}$ & $\begin{array}{l}\text { anti-SRBC PFC } \\
\text { /culture }\end{array}$ \\
\hline complete medium & - & $1160 \pm 135$ \\
complete medium & + & $3787 \pm 143$ \\
- GSH & + & $3533 \pm 53$ \\
- cystine & + & $<30$ \\
- cystine, - GSH & + & $<30$ \\
\hline
\end{tabular}

BALB c spleen cells $(6 \times 106)$ were cultured with SRBC in $\mathrm{m} l$ GSH - and cystine-free RPMI medium containing FCS for days. When complete medium was employed, $\mathrm{m} l$ cystine and $\mathrm{m} l$ GSH were supplemented to the basal medium.

ウシ胎児血清 (FCS) (GIBCO), RPMI-1640 培地 (日水製薬)， ${ }^{35} \mathrm{~S}-\mathrm{L}$-cystine (RCC Amersham), L-cysteine hydrochloride, おょび $2 \mathrm{ME}$ (東京化成), L-cystine hydrochloride (石津製薬).

cystine や GSH を含まない RPMI-1640 培地は, Moore らの組成に従って調製した7).

(2) リンパ球の培養

マウス脾リンパ球 $\left(8 \times 10^{6}\right.$ 個 $)$ を $2 \times 10^{6}$ 個のヒツジ赤 血球 (SRBC) とともに, $10 \% \mathrm{FCS}$ を含む $2 \mathrm{ml}$ の RPMI-1640 培地中で, $5 \% \mathrm{CO}_{2}$ 下 $37^{\circ} \mathrm{C} に て 4$ 日間 培養した。培養容器として24穴の Nunc カルチャープレ 一トを用いた。すべての培養は, duplicate か triplicate で行った. プラーク形成細胞 (PFC) 数は, Jerne の方 法淿により計数した. cystine-free RPMI-1640 培地で培 養するときは, $6 \times 10^{6}$ 個の脾細胞を $2 \times 10^{6}$ 個の $\mathrm{SRBC}$ と ともに $1 \mathrm{ml}$ の培地 (10\% FCS 含有) を用いて培養し た。この場合, cysteine や cystine の混入を防ぐため に, 脾細胞は培養開始前にハンクス液で 2 度洗浄して用 いた.

（3）マウスリンパ球への cystine の取り込み

脾細胞から Tris- $\mathrm{NH}_{4} \mathrm{Cl}$ 処理 $\left.{ }^{9}\right) に よ り$ 赤血球 ( $\mathrm{RBC}$ )を 除去したものをリンパ球標品として用いた， RBC (一) 脾細胞 $\left(4-6 \times 10^{6}\right)$ を $1 \mathrm{~m} l$ の $10 \%$ FCS を添加したcystinefree RPMI-1640 培地中で $0.1 \mathrm{mM}$ の ${ }^{35} \mathrm{~S}$-cystine (0.5 $\mu \mathrm{Ci})$ とともに保温した. $1 \mathrm{hr}$ 以内の反応は, 培地に 20mM HEPES を加えて pH7.2 とし空気中で行った.

一方, 長時間取り込み反応を行う場合には, HEPESを 加えず， $5 \% \mathrm{CO}_{2}$ 下で保温した. cysteine の取り込み を調べるときは $1 \mathrm{mM}$ の cysteine を $5 \mu \mathrm{Ci} / \mathrm{ml}$ の ${ }^{35} \mathrm{~S}$ cystine と混合し， $2 \mathrm{mM}$ の DTT により 30 分還元し たものを ${ }^{35} \mathrm{~S}$-cysteine 標品として用いた. すべての反応 は, duplicate で行った. 反応は, $4 \mathrm{ml}$ の氷冷したリン
酸緩衝生理食塩水(PBS)の添加により停止させ, $1,500 \times$ $\mathrm{g} 2$ 分間遠心後, も5一度 $4 \mathrm{ml}$ の PBS で細胞を洗浄し 取り达まれた放射能を測定した。

\section{結 果}

市販の FCS の大部分の lot では，2 ME を培地に添 加しないと SRBC に対して低い抗体応答しか得られな かった。しかし，10-5 Mの $2 \mathrm{ME}$ を培地に添加すると， 応答は著明に増強された（図 1 ).

cysteine を培養開始時に添加すると，抗体応答は増強 され, $5 \mathrm{mM}$ 程度で $2 \mathrm{ME}$ と同等の増強効果が認められ

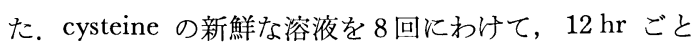
に逐時添加した場合は, その促進効果がさらに増強さ れ， $0.5 \mathrm{mM} \sim 1 \mathrm{mM}$ で最大の促進効果が得られた（図 $1 \mathrm{~A})$. 抗体応答は cysteine のかわりにその酸化型であ る cystine を用いた場合もほぼ同等に促進されたが逐時 添加による効果の増強はまったく見られなかった（図 1 B ). 2 MEや cyst(e)ine による抗体応答の促進は, こ れらの化合物により 10 20\%しかリンパ球の生存率が増 加しなかったことから非特異的な生存率の改善のみによ っては説明できないと思われる。つぎにcysteine が抗体 応答を増強する場合, それが栄養因子として必要なの か，たんに SH 化合物として関与しているのかについて 検討するために, cystine および GSH-free RPMI-1640 培地を調製し in vitro 抗体応答の cystine 要求性につい て調べた。表 1 に示すように抗体応答は， cystine がな ければまったく起こらなかった。

元来, 低濃度 $(1 \mu \mathrm{g} / \mathrm{m} l)$ しか含まれていない $\mathrm{GSH}$ を除いても応答は匡とんど影響を受けなかったので，以 後の実験では常に GSH を加えた培地を用いた。培地 に cystine を添加しなければまったく応答が起こらなか ったことから，FCS や RBC から培地に持ち込まれる cyst(e)ine や GSH は無視できると思われる.

図 2 は, SRBCに対する抗体応答における cystine ま たは cysteine の dose-response 曲線を示す。抗体応答 は0.5mM以下の half cystine では低かったが $2.5 \mathrm{mM}$ 用いるとほぼ最大に達した。一方, cystine の dose-response 曲線は $2 \mathrm{ME}\left(10^{-5} \mathrm{M}\right)$ が共存すると約 1 オーダ 一程度低濃度側へ移行した，換言すれば，2 ME は cystine が0のときも，2.5mM のときも，応答を促進しな いが，不充分量の cystine $(0.05 \sim 0.5 \mathrm{mM})$ 存在下での み応答を著明に促進した。 cysteine は, cystine よりや や効果が大きい傾向にあったが，ほぼ同様な dose-response で抗体応答を誘起した。 しかし，cysteineを8回 にわけて逐時添加した場合は, cysteine の dose-response 曲線は低濃度側へ移行し，2ME 存在下での cystineの 曲線とほぼ一致した。データは示さないが，同様な結果 は胸腺非依存性抗原である DNP-Ficoll に対する抗体応 
答の系でも得られた. 通常, RPMI-1640培地は0.4mM 程度の half-cystine を含有しており，これは最大の応答 を得るには不充分量であることが図 2 の結果から示唆さ れた。

以上のデータおよび培地中では, cysteine は容易に cystine に酸化される事実を考慮すると，抗体産生は cystine によっても增強されるが， cysteine の活うがり ンパ球によってより効率的に利用されること，および cystine のリンパ球による利用が $2 \mathrm{ME} に よ り$ 促進され ている可能性のあることが示唆された.

そこで, ${ }^{35}$ S-cystineを用いて，そのリンパ球への取り 込みが $2 \mathrm{ME}$ によ促進されるかどらかについて検討し た。図 3 Aに示すように, cysteine は cystineよりも $5 \sim 6$ 倍速くリンパ球へ取り込まれた。 さらに $10^{-5} \mathrm{M} の$ $2 \mathrm{ME}$ が共存すれば, cystine の取り込みは約 2.5 倍加速

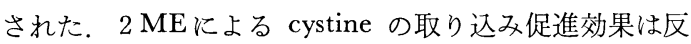
応時間を $24 \mathrm{hr}$ まで延長しても持続的に認められた。

つぎに in vitro 抗体産生および ${ }^{35} \mathrm{~S}$-cystine の取り込及

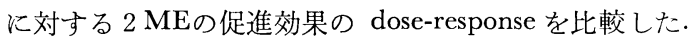
図 4 に示すように両者によい一致がみられ，2 MEの抗 体応答増強効果に拈いて cystine の取り込みを促進する ことが重要であることが示唆された.

\section{考 察}

RPMI-1640培地は cysteine を cystine の形で含有し ている7). 筆者らは, Toohey の報告 ${ }^{6}$ にあるように, $1 \mathrm{mM}$ の cysteine を培地に加えても $1 \mathrm{hr}$ 以内に cystine に酸化されてしまうことを確かめた。 したがって通常の 培責条件では, cysteine を与えても cystine としてリン パ球へ供給されると考えるべきであろう，Eagle らは10 ほとんどすべての動物細胞株が cystathionase 経路を火 くために，その増殖に cyst(e)ine を要求することを報 告している。筆者らの cystine-free RPMI-1640 培地を 用いた実験より， cyst(e)ine がマウスリンパ球による抗 体産生において，必須の栄養因子であることが明確に示 された（表1, 図 2 ).

したがってリンパ球が抗体産生細胞一分化, 増殖する ためには, cysteine を効率的に細胞へ供給することが重 要であると考えられる。図 2 に示したよらに， cysteine の新鮮な溶液を遂時添加するか, cystine に $2 \mathrm{MEを}$ 共存 させた場合に，抗体応答はもっとも効率的に惹起され た。 ヒトの末梢血リンパ球に打いても報告されているよ らに ${ }^{11)}$, マウスリンパ球は cystineを cysteine の少な くとも $1 / 5$ の速度でしか取り込むことができなかった。 しかし cystine の取り込み速度は $10^{-5} \mathrm{M}$ の $2 \mathrm{ME}$ 存在下

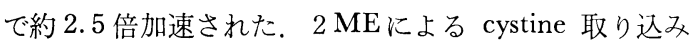
の促進は，脾リンパ球の $\mathrm{T}$ 細胞画分および $\mathrm{B}$ 細胞画分で 同等に認められた (未発表データ). 2.5〜 $5 \mathrm{mM}$ の高濃
度の half cystine を加えれば，2 MEにより増強された 応答と同程度の応答を得ることができる。この条件下で は, 細胞内に $2 \mathrm{ME}$ 存在下に匹敵する量の cystine が取 り込まれることを確認した。これらの結果は, in vitro 抗体産生の促進に拈ける $2 \mathrm{ME}$ の役割の一つとして, そ れ自身ではリンパ球へ取り込まれにくい cystine のリン パ球への取り込みを促進することがきわめて重要である ことを示唆した。

$2 \mathrm{ME} よ る$ cystine の取り込み促進は $2 \mathrm{ME}$ がたん にcystineを還元し, 取り込及速度の大きい cysteine を 生成するためだけではないと考えられる。すなわち, cystine と $2 \mathrm{ME}$ を混合すると, 最初の数時間には cys teine および cysteine と $2 \mathrm{ME} の$ mixed disulfide の両 方が生成しているのが観察された。しかし, それ以後は cysteine は cystine に再酸化され, mixed disulfide が 唯一の生成物となった。このような条件下でも， $2 \mathrm{ME}$ による取り込み促進効果は依然として観察されたので, mixed disulfide 自身もりンパ球へ取り込まれやすいこ とが想定された。事実 mixed disulfide は, cysteine と 汪汇匹敵する速度でリンパ球に取り込まれ，cystineよ りもはるかに効力ょく抗体応答を惹起できることを確か めた（投稿準備中）.

cystine の取り込み促進効果のみが，2ME の抗体応 答促進における唯一の機作ではないであろう。ヒト緎維 芽細胞を cystin-free 培地に移すと細胞内の GSH 濃度が

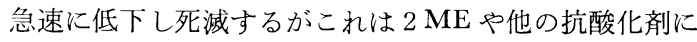
よって保護されることが知られている ${ }^{12)}$ ，筆者らはリン 八球を同様な条件に移すと, やはり急速に死隇しはじめ るが，これは抗体産生促進活性の高い $\mathrm{SH}$ 化合物によっ て效果的に保護されることを認めている(投稿準備中). したがって,このようなリンパ球の生存率増加の効果も 抗体産生増強の一つの因子となっているであろう。

$2 \mathrm{ME}$ による抗体応答促進効果は, FCS 成分の活性 化を介して発現するといら報告がある32. しかし，最近 筆者らは，この問題を再検討した結果，2MEによる FCS の活性化現象は見かけ上のものであり，FCS 成分 に disulfide 結合した $2 \mathrm{ME}$ に由来するものであること を明らかにした。 また，このような結合型の $2 \mathrm{ME}$ free の $2 \mathrm{ME}$ と同様究極的には cystine の取込及促進 といら共通の機構によって抗体産生を増強するであろら といら証拠も得ている(投稿準備中).

筆者らの今回の実験から, リンパ球を通常の RPMI1640 培地で培養する場合は, cystine が制限栄養因子と なっていることが示された。 したがって， cystine のリ ンバ球への取り込みに影響を与えるすべての因子が in vitro 抗体応答を変動させる可能性のあることに注意すべ きであろら。 


\section{文 献}

1) Click, R.E., et al.: Cell. Immunol. 3: 264-276, 1972.

2) Harris, J.M., et al.: J. Immunol. 116: 10711077, 1976.

3) Opitz, H.G., et al.: J. Exp. Med. 145: 10291038, 1977.

4) Hoffeld, J.T., Oppenheim, J.M.: Eur. J. Immunol. 10: 391-395, 1980.

5) Ohmori, H., Yamamoto, I.: Immunopharmacol. 3:333-345, 1981.

6) Toohey, J.I.: Proc. Natl. Acad. Sci. USA 72: 73-77, 1975.
7) Moore, G.E., et al.: J.A.M.A. 199: 519-524, 1967.

8) Jerne, N.K., Nordin, A.A.: Science 140: 405, 1963.

9) Mishell, B.B.: Selected methods in cellular immunology (eds. Mishell B.B. and Shiigi, S.M.) Freeman and Company, San Francisco, 1980, p 3-27.

10) Eagle, H. et al.: Proc. Natl. Acad. Sci. USA 56: 156-163, 1966.

11) Schneider, J.A., et al.: Pediat. Res. 2: 441450, 1968.

12) De Brabander, M. et al.: Int. J. Immunopharmacol. 1: 93-100, 1979. 